\title{
Allozyme variability in Bulgarian wild boar populations
}

\author{
Ettore RANDI, Giovanna MASSEI and Peter GENOV
}

Randi E., Massei G. and Genov P. 1992. Allozyme variability in Bulgarian wild boar populations. Acta theriol. 37: $271-278$.

Genetic variability in 42 wild boars Sus scrofa Linnaeus, 1758 sampled from two Bulgarian populations was studied using multilocus allozyme electrophoresis. A sample of 37 wild boars from central Italy was used for comparison. Percent polymorphism (over 40 studied loci) and heterozygosity were higher in southern Bulgaria $(P=12.5$; $H=0.028)$ than in northern Bulgaria $(P=5.0 ; H=0.025)$ wild boar populations. Nei's genetic distance $(D=0.002)$ and Wright's $F_{S T}(0.05)$ indicated the existence of significant $(p<0.01)$ genetic divergence among the two populations. Italian wild boars showed higher variability $(P=20 ; H=0.049)$, and their average genetic distance from the Bulgarian samples was $D=0.013$. Genetic variability of Bulgarian wild boar populations might be determined by their demographic histories (bottlenecks, isolation and expansion), and by possible cross-breeding with domestic pigs. Genetic divergence between populations is correlated with morphometric variation between the northern plain and the southern mountain Bulgarian wild boars (Genov et al. 1991). These findings suggest the possibility of natural selection and adaptation to different habitats.

Istituto Nazionale per la Fauna Selvatica, via Cà Fornacetta 9, 40064 Ozzano Emilia (BO), Italy (ER); Parco Naturale della Maremma, Loc. Pianacce, 58010 Alberese (GR), Italy (GM); Bulgarian Academy of Sciences, Institute of Zoology, Boul. Osvobozhdenie 1, 1000 Sofia, Bulgaria (PG)

Key words: Sus scrofa, population genetics, allozyme variability, electrophoresis, Bulgaria

\section{Introduction}

A simultaneous increase in number and distribution range of wild boar Sus. scrofa Linnaeus, 1758 populations occurred in recent years over the whole of Europe. This trend have been favoured by the action of several factors such as the improvement of habitat conditions following farmers' abandonmer.t of some rural areas, variations in type and extension of dominant plantation crops, introduction and restocking of wild boar populations, limitations to hunting and better management practices (Geptner et al. 1961, Pavlov et al. 1974, Fadeev 1975 and 1989, Genov 1981, Erkinaro et al. 1982, Saez-Royuela and Telleria 1986, Apollonio et al. 1988).

Wild boars disappeared from many regions in Bulgaria during local wars and World J/ar I (1912 - 1918) due to increasing hunting pressure. The formerly widespread and continuous population (Ivanov 1906) was fragmented in small isolates in the Rhodope mountains, Sredna Gora mountains, and in Rila - Pirin 
Massiv, in southern Bulgaria; in the eastern part of the Balkan Range; and in Dobrudja and Ludogorie forests in north-eastern Bulgaria (Genov et al. 1991) (Fig 1). Wild boar populations increased and expanded their ranges in Bulgaria starting from the end of the 1950s. In north-eastern Bulgaria reintroduction and restocking were carried out using captive-reared local animals. The isolated southern mountain populations expanded during the 60 s and recently came again in contact. Genov et al. (1991) indicate the possibility of cross-breeding of domestic pigs, reared in semi-wild conditions, with wild boars in the norheastern part of the country (Balkan range, Ludogorie and Dobrudja plains). Notwithstanding the recent expansion of population ranges, northern and southern Bulgaria wild boars seem to be actually isolated, because the Balkan Range and many humaninhabited areas constitute effective barriers to dispersal.

Genov et al. (1991) studied skull characters of wild boars from Bulgaria using multivariate methods, and described the exsistence of two morphological ecotypes: a larger type occurring in the northern plains, and a smaller type occurring in the southern mountains. In this paper we analyse genetic variability of wild boars sampled from the two Bulgarian populations using multilocus protein electrophoresis. Aim of the study was to describe genetic polymorphism within populations, and to estimate the extent of genetic divergence between south and north Bulgaria populations. A sample of wild boars belonging to a population from central Italy has been used for comparison.

\section{Materials and methods}

Tissue samples (liver and heart) were obtained from 42 Bulgarian and 37 Italian wild boars. Bulgarian wild boars were collected from the following areas (Fig. 1): northern Bulgaria (Eastern Balkan range and Ludogorie plains, $\mathrm{n}=16$ ); southern Bulgaria (Rhodope, Sredna Gora, Ograzden, Pirin and Rila Mountains, $n=26$ ). Those two populations belong to the north and south Bulgarian wild boar phenotypes, which have been previously described by means of multivariate craniometrical analysis (Genov et al. 1991).

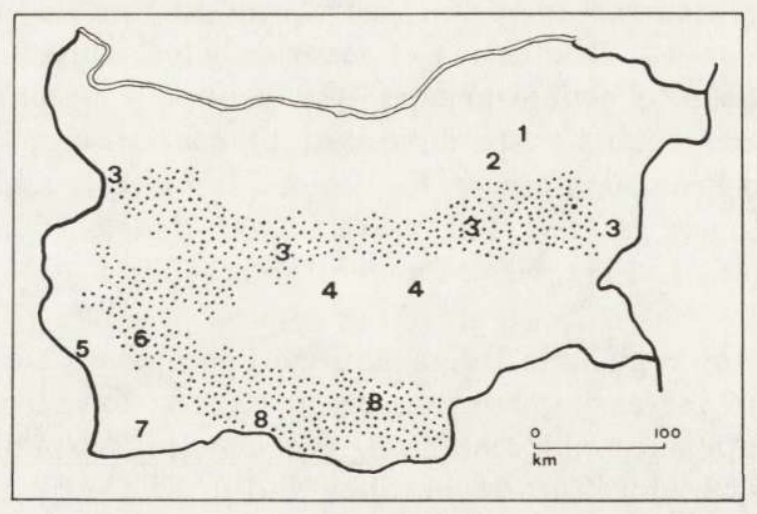

Fig. 1. Map of Bulgaria. Regions where the wild boar samples (sample size) were collected are shown: 1. Dobrudja (10); 2. Ludogorie (6); 3. Balkan Range (9); 4. Sredna Gora (4); 5. Ograzhden (2); 6. Rila Massiv (5); 7. Pirin Mountains (2); 8. Rhodopes Mountains (4). 
Tissue samples were stored at $-20^{\circ} \mathrm{C}$ during field collection, and $-80^{\circ} \mathrm{C}$ in laboratory, until processing. About $1 \mathrm{gr}$ of each tissue was separately homogenated in $1 \mathrm{ml}$ of $0.01 \mathrm{M}$ Tris $/ \mathrm{HCl}, \mathrm{pH}$ 7.5, 0.001 M Na2.EDTA, 0.001 M B-mercaptoethanol buffer, and centrifuged for $15 \mathrm{~min}$ at 13,000 $\mathrm{rpm}$, at $4^{\circ} \mathrm{C}$. Clear supernatants were diluted in 1 volume of a $40 \%$ glycerol solution, aliquoted in Microtiter plates, and frozen at $-80^{\circ} \mathrm{C}$ until used. Vertical (VPAGE) and horizontal (HPAGE) polyacrylamide gel electrophoresis ( $7.5 \%$ monomers concentration in the resolving gels) were used to study allozyme variation at 40 loci, using the following buffer systems: 1 - discontinuous Tris/Glycine, pH 8.3 VPAGE (Davis 1964): AMY-1, AMY-2 (3.2.1.1); MDH-1 (1.1.1.37); FUM (4.2.1.2); non-enzyme heart proteins (HPT-1 to HPT-8); CK (2.7.3.2); LDH-1, LDH-2 (1.1.1.27); G6PDH (1.1.1.42); 2 discontinuous Tris/Glycine, pH 8.5 VPAGE (Jolley and Allen 1965): SOD-1, SOD-2 (1.15.1.1); ME-1, ME-2 (1.1.1.40); HB-1, HB-2; PGM-2, PGM-3 (2.7.5.1); GPI (5.3.1.9); GOT-1 (2.6.1.1); GDH-1, GDH-2 (1.1.1.47); AK (2.7.4.3); 3 - Barbituric acid, pH 7.0 VPAGE (Williams and Reisfeld 1964): leucyl-alanine PEP-A (3.4.11.); leucyl-glycyl-glycine PEP-B (3.4.11.); 4 - Phosphate, pH 7.0 HPAGE (Harris and Hopkinson 1976): 6PGD (1.1.1.44); 5 - Tris/Borate pH 8.9 VPAGE (McLellan 1982): liver a-naphthylacetate esterases (EST-1, EST-2, EST-3; 3.1.1.1); 6 - Tris/Phosphate, pH 8.3 HPAGE (Harris and Hopkinson 1976): MPI (5.3.1.8); 7 - Histidine/MES, pH 6.1 VPAGE (McLellan 1982): IDH-2 (1.1.1.42); GOT-2 (2.6.1.1); ACP (3.1.3.2); ADH (1.1.1.1). Several enzymes were resolved in more than one buffer system. Staining recipes were adapted from Harris and Hopkinson (1976). Electromorphs were presumed to have a simple genetic basis, and were considered as alleles. Alleles were coded by their mobility from the starting line, with the most anodal allele coded as "a". Isozymes were coded with numbers, -1 being the most anodal.

The program BIOSYS-1 (Swofford and Selander 1989) was used to compute allele frequencies, effective allele number $(A)$, percent polymorphic loci $(P)$, and heterozygosity $(H)$ values. Agreement with Hardy-Weinberg expectations was tested by chi-square test (Sokal and Rohlf 1981). Genetic differences among populations were estimated by $F$-statistics (Wright 1978), and tested with contingency chi-squares of heterogeneity (Workman and Niswander 1970). Nei's (1978) and Rogers' (1972) genetic distance matrices were computed, and were clusterized using UPGMA (Sneath and Sokal 1973) method.

\section{Results}

Eight loci (Ck, Gpi, Got-1, Hpt-4, Hb-1, Pgm-1, Amy-1, Gdh-2) out of 40 we have resolved, were polymorphic in one or more wild boar population (Table 1). All enzymes showed two alleles, except AMY-1 which showed four alleles. The three populations were quite different in average values of genetic variability. CK, HB-1 and GOT-1 were polymorphic only in the Italian population, which, therefore, showed percent polymorphism $(P=20.0)$ about $2-3$ times higher than the Bulgarian populations $(P=12.5$ and 5.0). Effective allele number was $A=1.0$ and 1.1 in north and south Bulgaria, and it was 1.3 in the Italian sample. Average heterozygosity was about $40 \%$ higher in Italian $\left(H_{0}=0.049, H_{\mathrm{e}}=0.056\right)$ than in Bulgarian samples ( $\left.H_{0}=0.025-0.028, H_{\mathrm{e}}=0.025-0.035\right)$. Genotype frequencies at polymorphic loci were in Hardy-Weimberg equilibrium, with the exception of $P g m-1$ and Amy-1 in south Bulgaria, and of $H b-1$ and Amy-1 in Italy. These loci showed significantly $(p<0.01)$ less than expected heterozygotes. GPI, PGM-1 and AMY-1 were polymorphic in south Bulgaria, but monomorphic in north Bulgaria wild boar samples. Therefore, genetic variability estimates were, on average, higher in south Bulgaria wild boars (Table 1). Major contributions to average Tissue 
Table 1. Allele frequencies at polymorphic loci and estimates of genetic variability at 40 enzyme loci in three populations of wild boar $(n=$ sample size; $P=$ percent polymorphic loci; $A=$ effective allele number; $H_{0}=$ observed heterozygosity; $H_{\mathrm{e}}=$ Hardy-Weinberg expected heterozygosity).

\begin{tabular}{|c|c|c|c|c|}
\hline Locus & $\begin{array}{c}\text { Allele } \\
\mathbf{n}\end{array}$ & $\begin{array}{c}\text { north Bulgaria } \\
\text { (16) }\end{array}$ & $\begin{array}{l}\text { south Bulgaria } \\
\qquad(25)\end{array}$ & $\begin{array}{l}\text { Italy } \\
(37)\end{array}$ \\
\hline$C k$ & $\begin{array}{l}a \\
b\end{array}$ & $\begin{array}{l}0.000 \\
1.000\end{array}$ & $\begin{array}{l}0.000 \\
1.000\end{array}$ & $\begin{array}{l}0.054 \\
0.946\end{array}$ \\
\hline$H p t-4$ & $\begin{array}{l}a \\
b\end{array}$ & $\begin{array}{l}0.563 \\
0.437\end{array}$ & $\begin{array}{l}0.600 \\
0.400\end{array}$ & $\begin{array}{l}0.662 \\
0.338\end{array}$ \\
\hline$H b-1$ & $\begin{array}{l}a \\
b\end{array}$ & $\begin{array}{l}1.000 \\
0.000\end{array}$ & $\begin{array}{l}1.000 \\
0.000\end{array}$ & $\begin{array}{l}0.865 \\
0.135\end{array}$ \\
\hline Got-1 & $\begin{array}{l}a \\
b\end{array}$ & $\begin{array}{l}0.000 \\
1.000\end{array}$ & $\begin{array}{l}0.000 \\
1.000\end{array}$ & $\begin{array}{l}0.041 \\
0.959\end{array}$ \\
\hline Gpi & $\begin{array}{l}a \\
b\end{array}$ & $\begin{array}{l}0.000 \\
1.000\end{array}$ & $\begin{array}{l}0.020 \\
0.980\end{array}$ & $\begin{array}{l}0.162 \\
0.838\end{array}$ \\
\hline$P g m-1$ & $\begin{array}{l}a \\
b\end{array}$ & $\begin{array}{l}1.000 \\
0.000\end{array}$ & $\begin{array}{l}0.960 \\
0.040\end{array}$ & $\begin{array}{l}0.932 \\
0.068\end{array}$ \\
\hline$A m y-1$ & $\begin{array}{l}a \\
b \\
c \\
d\end{array}$ & $\begin{array}{l}1.000 \\
0.000 \\
0.000 \\
0.000\end{array}$ & $\begin{array}{l}0.800 \\
0.000 \\
0.200 \\
0.000\end{array}$ & $\begin{array}{l}0.203 \\
0.080 \\
0.703 \\
0.014\end{array}$ \\
\hline$G d h-2$ & $\begin{array}{l}a \\
b\end{array}$ & $\begin{array}{l}0.625 \\
0.375\end{array}$ & $\begin{array}{l}0.340 \\
0.660\end{array}$ & $\begin{array}{l}0.514 \\
0.486\end{array}$ \\
\hline $\begin{array}{l}P \\
A \\
H o \\
H e\end{array}$ & & $\begin{array}{l}5.0 \\
1.0 \\
0.025 \\
0.025\end{array}$ & $\begin{array}{l}12.5 \\
1.1 \\
0.028 \\
0.035\end{array}$ & $\begin{array}{l}20.0 \\
1.3 \\
0.049 \\
0.056\end{array}$ \\
\hline
\end{tabular}

Table 2. Genetic divergence among wild boar populations estimated as $F_{S T}$ (Wright 1978), and assayed with contingency chi-square test (Workman and Niswander 1970). (a) n.s. = not significant; ${ }^{* *}=p<0.01 ;{ }^{* * *}=p<0.001$.

\begin{tabular}{|c|c|c|c|c|}
\hline \multirow{3}{*}{$\begin{array}{l}\text { Locus } \\
C k\end{array}$} & \multicolumn{4}{|c|}{$F_{S T}$ estimates between } \\
\hline & \multicolumn{2}{|c|}{ Italy and Bulgaria } & \multicolumn{2}{|c|}{ south and north Bulgaria } \\
\hline & 0.037 & n.s. (a) & 0.000 & n.s. \\
\hline$H p t-4$ & 0.007 & n.s. & 0.001 & n.s. \\
\hline $\mathrm{Hb}-1$ & 0.094 & $* *$ & 0.000 & n.s. \\
\hline Got-1 & 0.027 & n.s. & 0.000 & n.s. \\
\hline Gpi & 0.091 & $* *$ & 0.010 & n.s. \\
\hline$P g m-1$ & 0.022 & n.s. & 0.020 & n.s. \\
\hline$A m y-1$ & 0.440 & $* * *$ & 0.111 & $* * *$ \\
\hline$G d h-2$ & 0.055 & ** & 0.081 & $* *$ \\
\hline Average & 0.145 & $* * *$ & 0.051 & $* *$ \\
\hline
\end{tabular}


Table 3. Nei's (1978) unbiased (above diagonal), and Rogers (1972) (below diagonal) genetic distances among three wild boar populations.

\begin{tabular}{lccc}
\hline Population & 1 & 2 & 3 \\
\hline 1 - south Bulgaria & - & 0.002 & 0.009 \\
2 - north Bulgaria & 0.015 & - & 0.016 \\
3 - Italy & 0.030 & 0.036 & - \\
\hline
\end{tabular}

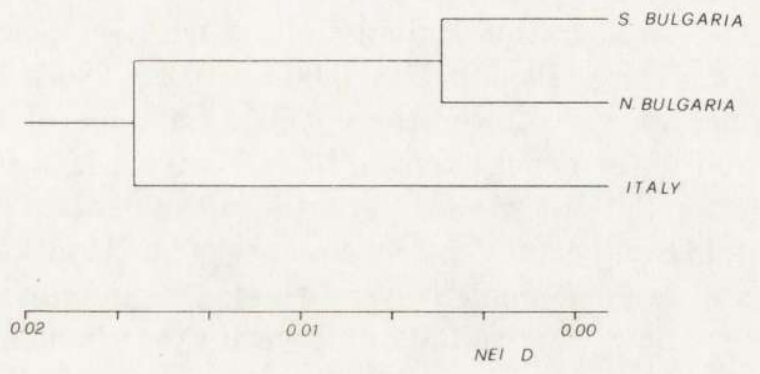

Fig. 2. UPGMA dendrogram of Nei's (1978) unbiased standard genetic distances among two Bulgarian and one Italian wild boar populations.

samples were stored at $-20^{\circ} \mathrm{C}$ during field collection, and $-80^{\circ} \mathrm{C}$ in laboratory, until heterozygosity were due to HPT-4 and GDH-2 (single locus $H_{0}$ ranging from 0.45 to 0.49 ) in both populations. AMY-1 was polymorphic in south Bulgaria only, with a quite high value of heterozygosity $\left(H_{0}=0.32\right)$.

Genetic divergence among populations was estimated by means of $F_{S T}$ (Wright 1978), which measures the among population percent genetic variance (Table 2). Average $F_{S T}$ values were 0.145 between Italy and Bulgaria, and 0.051 between south and north Bulgaria, which means that about $15 \%$ and $5 \%$, respectively, of total genetic variance was distributed among populations. Both $F_{S T}$ estimates were significant (contingency chi-square test; Workman and Niswander 1970). Genetic divergence between Italy and Bulgaria was extensive, and was attributable to allele frequency variability at four loci (Hb-1, Gpi, Amy-1, Gdh-2). Genetic diver- gence between south and north Bulgaria was smaller, but nevertheless significant, and attributable to only Amy-1 and Gdh-2 loci (Table 2).

Nei's (1978) genetic distances among wild boar populations (Table 3) were clusterized using UPGMA procedure (Fig. 2). South and north Bulgaria populations were joined at a distance 0.002 , while Italy and Bulgaria populations were clustered at a distance 0.013 , more than six times larger. The cophenetic correlation was 0.87 . 


\section{Discussion}

We have found differences in estimates of genetic variability, and significant genetic divergence between two Bulgarian wild boar populations. Percent polymorphic loci and heterozygosity was lower in the northern than in the southern population ( $P=5.0$ and $12.5 ; H_{0}=0.025$ and 0.028 , respectively). Nei's genetic distance was 0.002 , and Wright's $F_{S T}$ was 0.051 between the two wild boar populations. A sample of wild boars from central Italy showed higher genetic variability $\left(P=20 ; H_{0}=0.049\right)$ and greater genetic divergence $\left(D=0.013, F_{S T}=0.14\right)$ from the Bulgarian populations.

Randi et al. (1989) studied some Italian and French wild boar populations and obtained values of $P=10-14$ and $H=0.005-0.029$. Nei's genetic distances among local populations were lower than 0.001. Samples of native Sardinian domestic pigs showed lower genetic variability $(P=0.03 ; H=0.005)$. It is usual that local wild boar populations show different levels of genetic variability (Smith et al. 1980, Hartl and Csaikl 1987), as consequence of bottlenecks, small numbers, hunting pressure and management. Nevertheless, genetic variability of the two Bulgarian samples we have studies falls well within the range of $P$ and $H$ values estimated in other wild boar and large mammal populations (Nevo et al. 1984).

Several causes may have resulted in the observed genetic variability in Bulgarian wild boars. The history of northern and southern populations is different. The northern, formely widespread, wild boar population, strongly decreased during the $50 \mathrm{~s}$. Moreover, cross-breeding with free-ranging domestic pigs has been described in that region (Genov et al. 1991). Bottleneck effect (Nei et al. 1975) may have reduced its genetic variability. Possible gene flow between domestic and wild pigs seem to have not increased genetic variability of the northern population in comparison with southern wild boars. According to Epstein (1971) and Bökönyi (1974) in the 7th millennium B.C. domestic pigs already occurred in southeastern Europe and were locally domesticated. Rural pig breeds of ancient origins could possibly have maintained a genetic structure very similar to their parental wild populations (Randi et al. 1989, Mayer and Brisbin 1991, Mauget 1991). Moreover, it was documented the effectiveness of domestication and repeated bottlenecks in reducing genetic variability during human-mediated diffusion of mammalian species (Randi and Apollonio 1988).

The present southern Bulgaria wild boar population is a mixing of formely isolated mountain populations which dispersed and overlapped during the recent positive demographic trend. It is therefore possible that genetic divergence accumulated during the bottleneck and isolation phase. The recent dispersal and intermixing of previously isolated groups could have resulted in the observed higher genetic variability of the southern population. It is noteworth the low heterozygosity observed in southern wild boars $\left(H_{0}=0.028, H_{\mathrm{e}}=0.035\right)$, which was due to significant less than expected heterozygotes at PGM-1 and AMY-1 loci. These findings may indicate a Whalund effect (Hartl and Clarck 1991): we have 
considered as a single panmictic populations what in reality is a recent mixing of different populations, in a state of genetic non-equilibrium. The different demographic and population genetics histories, as well as the actual isolation, act to maintain the degree of observed genetic divergence between the southern and the northern Bulgaria wild boars.

Our genetic results are in agreement with the morphometric differences discovered by Genov et al. (1991) between northern plain and southern mountain wild boars in Bulgaria. Different ecological conditions (i.e. food availability and winter climate; Genov 1987, Genov, in press) could explain for most of morphometric variation, although the effects of local cross-breeding with pigs, and population histories could have a role. The genetic data reported in this paper suggest that population genetic factors are probably effective in determining divergence between the studied Bulgarian wild boars. We can not exclude (but not demonstrate) that natural selection may act to determine correlate variation at the morphometric and the alloenzymatic level, so determining divergent populations adapted to plain and mountain habitats, respectively.

\section{References}

Apollonio M., Randi E. and Toso S. 1988. The systematics of the wild boar (Sus scrofa L.) in Italy. Boll. Zool. 3: $213-221$.

Bökönyi S. 1974. The Pig. [In: History of domestic mammals in central and eastern Europe]. Akademia Kiado, Budapest: $201-225$.

Davis B. J. 1964. Disc electrophoresis. II. Method and application to human serum proteins. Ann. N. Y. Acad. Sci. 121: $404-427$.

Epstein H. 1971. Pig. [In: The origin of the domestic animals of Africa]. Edition Leipzig 2: $313-373$.

Erkinaro E., Heikura H., Lindgren L., Dulliainen E. and Sulkava S. 1982. Occurrence and spread of the wild boar (Sus scrofa L.) in eastern Fennoscandia. Memoranda Soc. Fauna Flora Fennica 58: $39-76$.

Fadeev E. 1975. Kaban v Evropejskoj casti SSSR. Ohota i ohotn. h-vo 1975, 2: 16 - 17.

Fadeev E. 1589. Specifika zaselenija kabanom severnoj casti niečernozemniego centra Rosii. Vestnik MGU, 16, 3: $45-50$.

Genov P. 1981. Die Verbreitung des Schwarzwildes (Sus scrofa L.) in Eurasien und seine Anapassung an die Nahrungsverhältnisse. Z. Jagdwiss. 27: $221-230$.

Genov P. 1987. Food composition in the wild boar (Sus scrofa attila Thomas) in the Danubian plain. Ecology (Sofia) 20: 47 - 57.

Genov P. Nurriture du sanglier (Sus scrofa attila Thomas, 1912) dans les montagnes de la Bulgarie. Ecology (Sofia) 25 (in press).

Genov P., Nikolov H., Massei G. and Gerasimov S. 1991. Craniometrical analysis of Bulgarian wild boar (Sus scrofa) populations. J. Zool., Lond. 225: 309 - 322.

Geptner V., Nassimovið A. and Bannikov A. 1961. Mlekopitajušcie Sovetskogo Sojuza. Vyšaja skola, Moskva, 1: 1 - 774 .

Harris H. and Hopkinson D. A. 1976. Handbook of enzyme electrophoresis in human genetics. North Holland Publ. Co., Amsterdam.

Hartl D. L. and Clark A. G. 1991. Principles of population genetics. Sinauer, Sunderland: 1- 000.

Hartl G. B. and Csaikl F. 1987. Genetic variability and differentiation in wild boars (Sus scrofa ferus L.); Comparison of isolated populations. J. Mammal. 68: 119 - 125. 
Ivanov H. 1906. Diva svinja, Bulg. lovets. 8, 7: $49-50$.

Jolley W. B. and Allen H. W. 1965. Formation of complexes between basic proteins of leucocytes and plasma globulins. Nature 208: $390-391$.

Mauget R. 1991. Du Sanglier au Porc domestique: modifications comportamentales et physiologiques liees a la domestication. Bull. Soc. Ecophysiol. 6 (1-2): 37 - 53.

Mayer J. J. and Brisbin I. L., Jr. 1991. Wild pigs in the United States. The University of Georgia Press, Athens and London: $1-313$.

McLellan T. 1982. Electrophoretic buffers for PAGE gels at various pH. Anal. Biochem. 126: 94 - 99.

Nei M. 1978. Estimation of average heterozygosity and genetic distance from a small number of individuals. Genetics 89: $583-590$.

Nei M., Maruyama T. and Chakraborty R. 1975. The bottleneck effect and genetic variability in populations. Evolution 29: 1- 10.

Nevo E., Beiles A. and Ben-Shlomo R. 1984. The evolutionary significance of genetic diversity: ecological, demographic and life history correlates. [In: Evolutionary dynamics of genetic diversity. G. S. Mani, ed.]. Lecture Notes in Biomathematics, Springer-Verlag, Berlin: 13 - 213.

Pavlov M., Korsakova I. and Lavrov M. 1974. Aklimatizacija ohotnice promyslovyh zverej i ptic SSSR. Kirovskoe otd. Volgo-Viatskoe, Kirov: 1 - 158.

Randi E., Apollonio M. and Toso S. 1989. The systematics of some Italian populations of wild boar (Sus scrofa L.): A craniometric and electrophoretic analysis. Z. Säugetierk. 54: $40-56$.

Randi E. and Apollonio M. 1988. Low biochemical variability in European fallow deer (Dama dama L.): natural bottlenecks and the effects of domestication. Heredity 61: $405-410$.

Rogers J. S. 1972. Measures of genetic similarity and genetic distance. Studies in Genetics, Univ. Texas Publ. 7213: 145 - 153.

Saez-Royuela C. and Telleria L. 1986. The increased population of the wild boar (Sus scrofa L.) in Europe. Mammal. Rev. 16: $97-101$.

Sneath P. H. A. and Sokal R. R. 1973. Numerical taxonomy. Freeman and Co., San Francisco.

Smith M. W., Smith M. H. and Brisbin I. L., Jr. 1980. Genetic variability and domestication in swine. J. Mammal. 61: $39-45$.

Sokal R. R. and Rohlf R. J. 1981. Biometry. Freeman and Co., San Francisco: 1-859.

Swofford D. L. and Selander R. K. 1989. BIOSYS-1. A computer program for the analysis of allelic variation in population genetics and biochemical systematics. Release 1.7. Illinois.

Williams D. E. and Reisfeld R. A. 1964. Disc electrophoresis in polyacrylamide gels: extension to new conditions of $\mathrm{pH}$ and buffers. Ann. N. Y. Acad. Sci. 121: $373-381$.

Workman P. L. and Niswander J. D. 1970. Population studies on southwestern Indian Tribes. II. Local genetic differentiation in the Papayo. Am. J. Human Genet. 22: 24 - 29.

Wright S. 1978. Evolution and the genetics of populations. Vol. 4. Variability within and among natural populations. University of Chicago Press, Chicago: $\mathrm{X}+1-580$.

Received 28 April 1992, accepted 26 August 1992. 